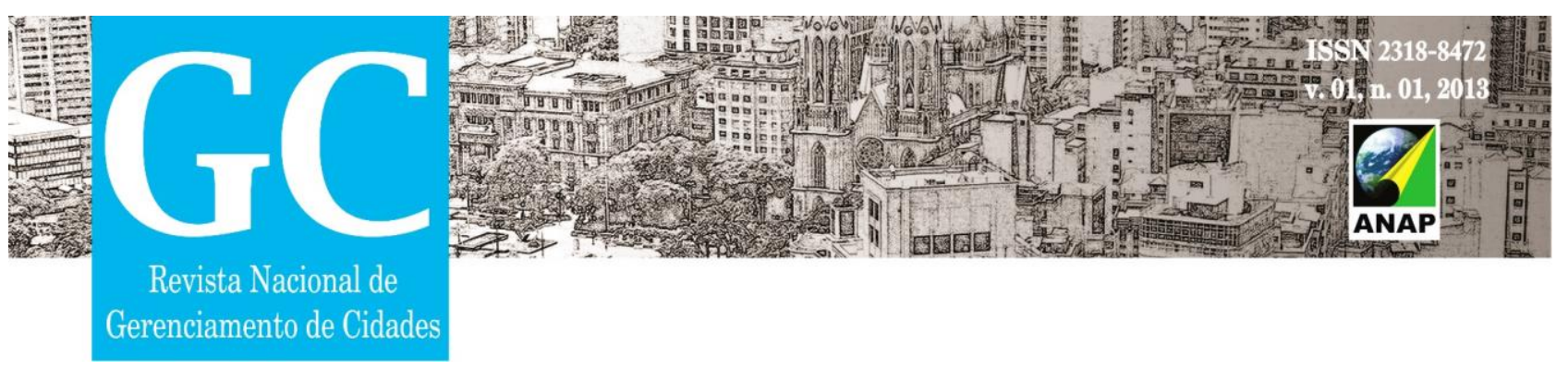

\title{
DEGRADAÇÃO AMBIENTAL E SUA RELAÇÃO COM A DRENAGEM URBANA - ESTUDO DE CASO EM DRACENA-SP
}

\author{
Marcela do Carmo Vieira ${ }^{1}$
}

\section{Sibila Corral de Arêa Leão Honda ${ }^{2}$}

RESUMO: O processo de ocupação do solo urbano deveria prever e regular aspectos de limitassem a degradação do ambiente natural, inclusive por meio de coleta adequada das águas pluviais. A drenagem, embora seja identificada como elemento relacionado à salubridade do ambiente urbano, quando mal projetada e executada, causa sérios danos ao solo, aos córregos e rios, e à população local, devido à grande velocidade e força que resulta do escoamento das águas, assim como ao acúmulo superficial. Da mesma forma, a impermeabilização do solo amplia o volume das águas captadas, aumentando a velocidade nos pontos de lançamento, impactando negativamente onde tais águas são lançadas, possibilitando surgimento de sulcos, ravinas, voçorocas e desaterro. Assim, a pesquisa que embasa este artigo buscou analisar dissipadores de energia proposto em dois pontos de lançamento no conjunto habitacional Emílio Zanatta, em Dracena-SP; que objetivaram recuperar a degradação ambiental causada pela força das águas na bacia hidrográfica onde o empreendimento foi implantado. A metodologia foi baseada em aprofundamento teórico e levantamentos documentais e in loco. Verificou-se que a ausência de projetos bem elaborados de drenagem urbana auxilia na degradação do meio

\footnotetext{
${ }^{1}$ Graduação em Arquitetura e Urbanismo, Graduação em Saneamento Ambiental, Mestranda. Docente no curso de Arquitetura e Urbanismo da Universidade do Oeste Paulista E-mail: marcela.c.vieira@hotmail.com ${ }_{2}^{2}$ Graduação em Arquitetura e Urbanismo, Mestrado e Doutorado em Arquitetura e Urbanismo. Docente e Coordenadora do curso de Arquitetura e Urbanismo da Universidade do Oeste Paulista. E-mail: sibila@unoeste.br
} 

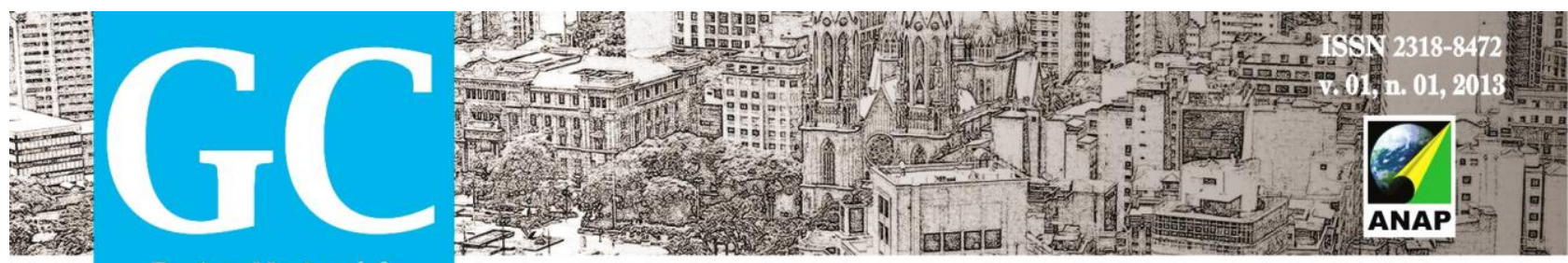

Revista Nacional de

Gerenciamento de Cidades

ambiente natural e construído, podendo deixar a população próxima em situação de risco devido a processos erosivos e deslizamentos, além da ruptura possível do sistema e alagamentos de áreas urbanizadas.

Palavras chave: Drenagem Urbana. Degradação Ambiental. Meio Ambiente Construído.

\section{INTRODUÇÃO}

No processo de urbanização brasileiro, observam-se sérios problemas de instalação de infraestrutura urbana. Quando de implantação adequada, a impermeabilização do solo pode resultar em surgimento de áreas inundáveis por projeto e/ou execução do sistema de drenagem mal resolvidos. Em contrapartida, em locais onde a pavimentação dos arruamentos e calçadas demoram a ser instalados, o escoamento superficial e a percolação das águas de chuva proporcionam desaterro, sulcos, ravinas e voçorocas junto às áreas residenciais e nos limites dos córregos e rios.

As águas carregam tudo o que seja possível em seu caminho, desde partículas suspensas no ar (poluição e poeira) até resíduos que foram lançados na rua e calçadas. Ao mesmo tempo, a velocidade da água que escorre superficialmente aumenta gradativamente com o aumento de seu volume; assim como a água que escorre no sistema de drenagem, ampliando sua força de carreamento.

Aliado a isso, a ocupação de áreas de fundo de vales ou próximas, favorece o impacto negativo sobre a saúde pública, afinal inundações nos leitos dos rios são um fenômeno natural nas épocas das chuvas no Brasil, que passam a ser um problema grave no meio urbano (RAIMUNDO, 2007).

No passado, com o intuito de se dar destino às águas pluviais, aumentava-se a velocidade do escoamento dessas águas, buscando reduzir seu acumulo nas áreas 


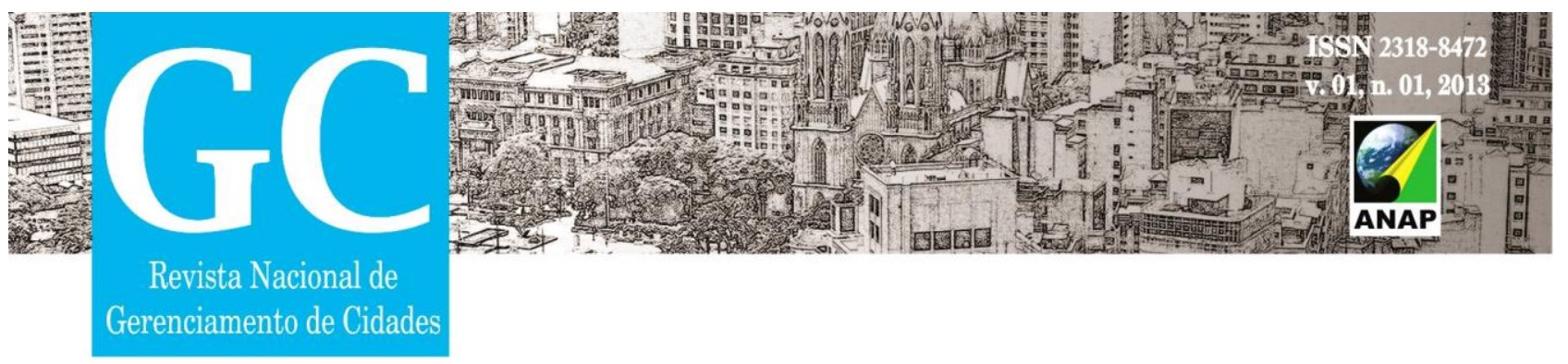

baixas; sendo construídas galerias e canalizações, assim como retificações de córregos; além da racionalização e normatização dos cálculos hidrológicos e abordagem científica e ambiental do ciclo hidrológico urbano.

Entretanto os picos de cheias aumentam a cada ano e a preocupação atual deixou de ser com o aumento da velocidade de escoamento, e passou a se buscar a desaceleração, reduzindo os picos de vazão por meio do armazenamento dos volumes escoados a montante, antes das inundações (CANHOLI, 2005).

Ou seja, as ocupações irregulares do solo e sua impermeabilização, e o descarte de resíduos nos corpos d'água, contribuem para as inundações, prejudicando a drenagem e causando problemas ambientais. E, com o objetivo de conter as águas, Governos aplicam medidas estruturais e não estruturais para tentar conter o excesso das águas pluviais na malha urbana.

Tais medidas se mostram necessárias a um gerenciamento de drenagem adequado. As medidas estruturais modificam o sistema pluvial, evitando os prejuízos decorrentes das enchentes, como a construção de estruturas de retardamento de fluxo. As medidas não estruturais atuam no âmbito social, por meio da educação ambiental e adequação do plano de drenagem com o plano diretor de desenvolvimento urbano (TUCCI, 1997).

A partir dessa realidade, o objetivo deste artigo é analisar aspectos que influenciam a drenagem urbana, desde ocupações irregulares por meio de estruturas convencionais, até novas propostas de estruturas e seus ganhos a médio e longo prazos, observando um ponto de lançamento das águas pluviais em uma bacia urbana na cidade de Dracena-SP.

Para estruturação da pesquisa que embasa este artigo algumas etapas foram fundamentais, como aprofundamento teórico, pesquisa documental, levantamentos in loco, e análise de documentos e projetos elaborados para minimizar os problemas encontrados. Foram feitas análises bibliográficas e estudo de projeto de drenagem urbana que trouxeram avanços para o planejamento e gestão das águas pluviais, no Conjunto Habitacional Emílio Zanata, na cidade de Dracena, no interior do Estado de São Paulo. 


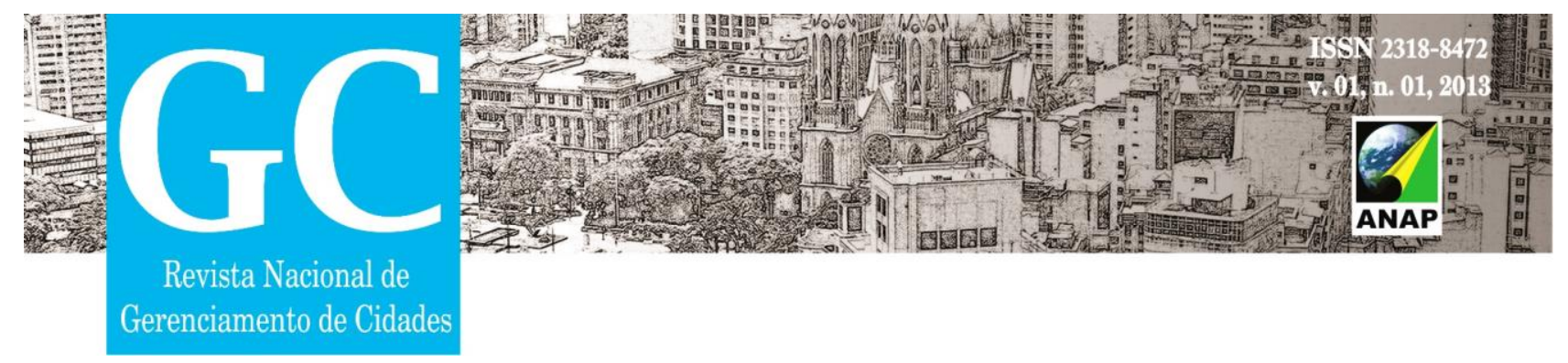

\section{INUNDAÇÕES, ENCHENTES E DRENAGEM URBANA}

Em condições normais, a água de um rio, ou mesmo de um pequeno córrego, escoa por canais naturais de dimensões suficientes para comportar sua vazão normal de água. No entanto, quando ocorrem chuvas intensas, a vazão aumenta possibilitando o transbordamento das águas, que passam a ocupar faixas laterais ao canal original, ou seja, ocupam a zona de inundação natural (várzea) nas inundações.

Em compensação, quando há ocupação dessas várzeas por população em áreas urbanizadas ou suburbanizadas, as enchentes são seu resultado. Essas, ao mesmo tempo, tornam-se ainda mais significativas devido à impermeabilização do solo, evitandose a possibilidade de percolação de parcela das águas no solo natural.

Além disso, quando a superfície por onde a água escoa não apresenta obstáculos, sua velocidade aumenta, resultando em maior rapidez de acúmulo de grandes volumes de água nos pontos mais baixos. E, com o crescimento das áreas urbanizadas, têm-se maiores acúmulos de água que não se infiltra no solo, escoando mais rápido em direção aos pontos críticos (CAVALHEIRO, 2008).

$\mathrm{Na}$ busca de solucionar esses problemas, vários aspectos precisariam planejados e controlados, como restrição da ocupação de áreas de várzea (ou áreas de preservação permanente também nas áreas urbanas) e adequado sistema de drenagem urbana, bem projetado e executado.

Segundo a Lei Federal $\mathrm{n}^{\circ} .11 .445$, de 05 de janeiro de 2007, define drenagem e manejo das águas pluviais urbanas como um "conjunto de atividades, infraestruturas e instalações operacionais de drenagem [...], de transporte, detenção ou retenção para o amortecimento de vazões de cheias [...] e disposição final das águas pluviais".

E, segundo o DAEE/CETESB (1980), entre os principais objetivos do sistema de drenagem estão: preservar as várzeas não urbanizadas, minimizando as interferências do escoamento com sua capacidade de armazenamento e com os ecossistemas aquáticos e terrestres; reduzir os problemas de erosão e sedimentação; e proteger a qualidade ambiental e o bem estar social. 


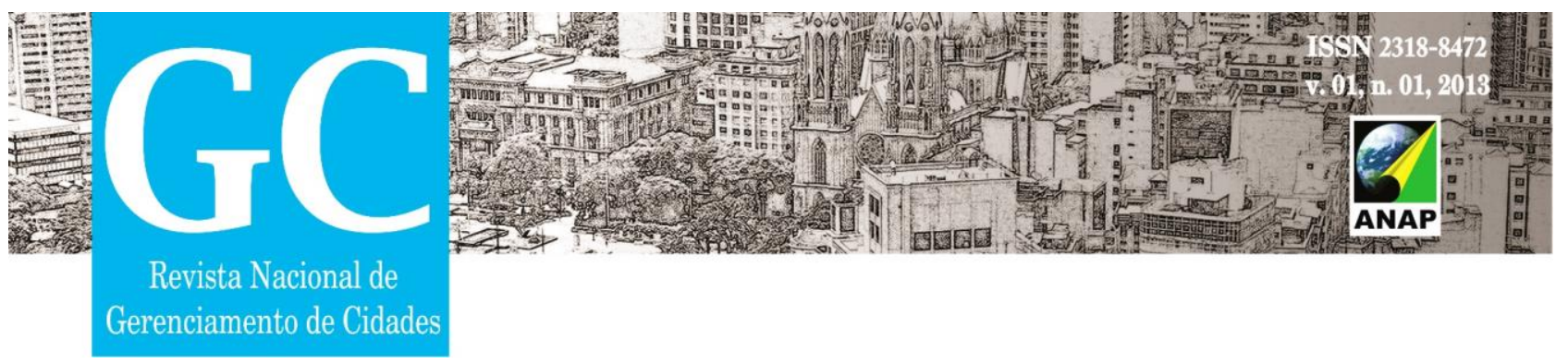

Assim, a drenagem urbana, como parte do saneamento básico, influi de forma efetiva para o planejamento e gestão urbanos, visto que se inexistente ou ineficaz, trará problemas de ordem social, ambiental e econômica, contrariando o propósito básico de bem estar nas cidades. E, passou-se a se exigir uma integração dos serviços de drenagem com os demais componentes do saneamento básico, como conduta de boas práticas de gestão das águas urbanas.

Ao mesmo tempo, a inclusão das águas fluviais na paisagem urbana e o reconhecimento da necessidade de se estabelecer o saneamento da bacia hidrográfica fortalece o conceito de sustentabilidade municipal, que é definido como um processo de mudança social e elevação das oportunidades da sociedade, compatibilizando, no tempo e no espaço, o crescimento e a eficiência econômicos, a conservação ambiental, a qualidade de vida e a equidade social, partindo de um claro compromisso com o futuro e a solidariedade entre gerações (BUARQUE, 1999).

A drenagem urbana com vistas à sustentabilidade ambiental tem incorporado o controle de escoamento in loco por meio da infiltração do excesso de água pluvial e do armazenamento. Isso provoca menor escoamento superficial, menor erosão do solo, menor poluição dos corpos d'água e diminuição dos custos com reparações à jusante. Os princípios para essa drenagem "sustentável" são a não ampliação da vazão máxima e um planejamento adequado das condições da bacia, visando ao cuidado em evitar a transferência de impactos para jusante (DIAS e ANTUNES, 2010).

Como medidas estruturais, para efetivação da drenagem "sustentável", as trincheiras de infiltração, valas e valetas de armazenamento e/ou infiltração, micro reservatórios individuais e telhados armazenadores, armazenamentos de detenção e retenção, e ainda pavimentos permeáveis, parques lineares entre outros são opções bastante relevantes.

Assim, de acordo com Champs (2009), o funcionamento da drenagem urbana obedece a princípios como o melhoramento da drenagem natural, a um funcionamento não contínuo, que depende da ocorrência de precipitações, o escoamento pluvial a ser drenado 

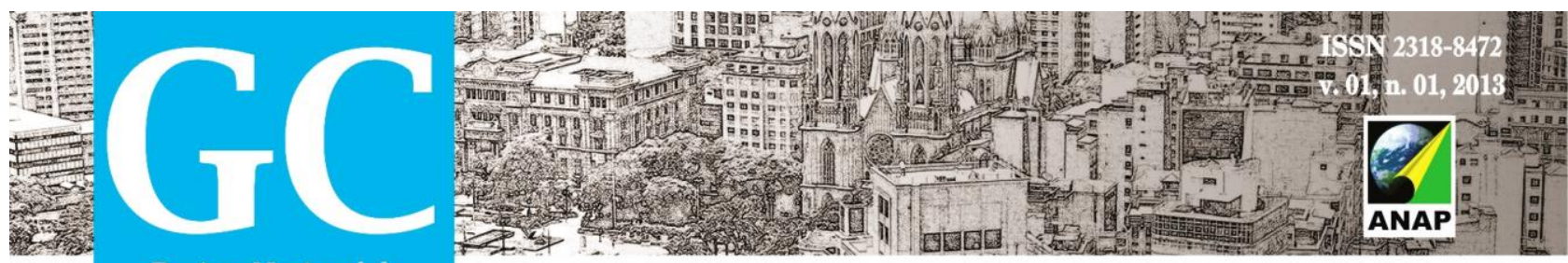

Revista Nacional de

Gerenciamento de Cidades

formado por água e sólidos, e ao sistema viário urbano, parte integrante da infraestrutura da microdrenagem.

\section{MICRODRENAGEM URBANA}

O desenvolvimento do processo de urbanização foi gerado pela Revolução Industrial, e este fenômeno ocasionou grandes transformações nos centros urbanos e na sociedade, transformações estas que trouxeram problemas de âmbito social, ambiental, de higiene e de saneamento básico, modificando a utilização do solo e transformando a paisagem urbana. Através do intenso processo de urbanização das cidades brasileiras, têm-se gerado muitos problemas de infraestrutura urbana, e especialmente em relação à drenagem de águas pluviais (VIEIRA e SÁ, 2011).

Segundo Champs (2009), o escoamento pluvial superficial sempre acontece, e a drenagem independe do meio, seja natural ou urbano. No entanto, com o acelerado e constante processo de urbanização, a drenagem precisa ser realocada incluindo novos espaços e novas direções, adquirindo vazões cada vez mais volumosas, principalmente devido à redução das possibilidades de percolação da água no solo. Isso demonstra que a drenagem no meio urbano adquire uma nova feição e constitui-se em um serviço de interesse público.

Além disso, com o crescente processo de urbanização, modificando os cursos naturais de água, esse escoamento passou a causar problemas no meio antrópico requerendo soluções que foram constantemente aprimoradas (VIEIRA e SÁ, 2011). E, sob o aspecto tecnológico, a drenagem urbana é componente de um sistema bastante complexo, formado por elementos hidráulicos de infraestrutura e manejo que inclui seu dimensionamento por meio de previsões hidrológicas e suas obras de implantação (CHAMPS, 2009).

O sistema de drenagem urbana apresenta diversas estruturas componentes, seja da microdrenagem como da macrodrenagem. Esta pode ser dividido em dois tipos: o sistema 


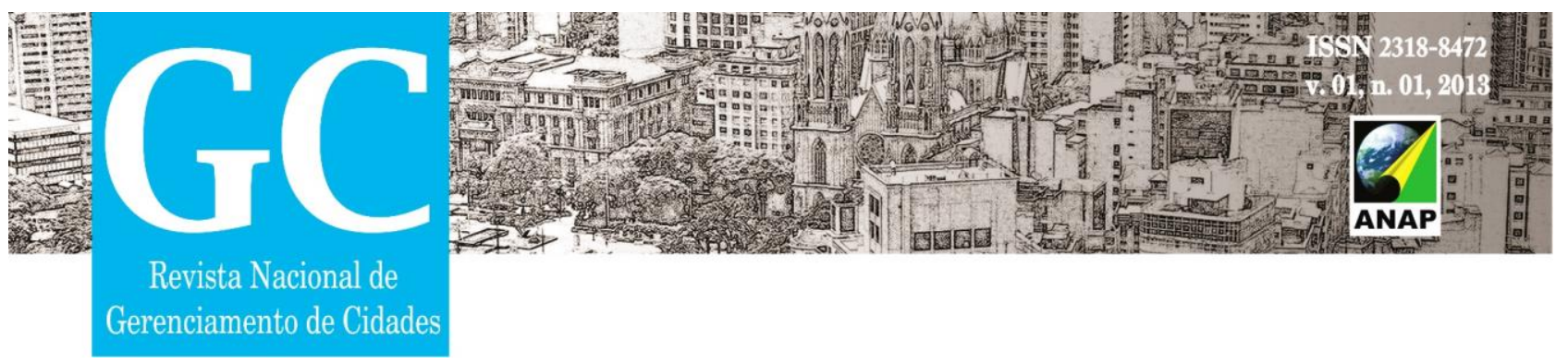

natural, constituído por cursos d'água perenes ou intermitentes, zonas de inundação natural, lagos permanentes e talvegues secos; e o sistema artificial, constituído por canais implantados no sistema natural, reservatórios de amortecimento de cheias, e demais obras auxiliares (CAVALHEIRO, 2008).

E a microdrenagem é a responsável pela captação da água pluvial em toda a bacia e pela sua condução até a macrodrenagem, lançadas em cursos d'água naturais, no oceano, em lagos ou até em solos bastante permeáveis. Embora a micro e a macrodrenagem sejam sistemas distintos, estão intimamente inter-relacionadas; e uma das estruturas auxiliares de grande importância, e que liga esses dois sistemas, é o dissipador de energia, que possibilita reduzir a velocidade de saída da água para a macrodrenagem (VIEIRA e SÁ, 2011; CAVALHEIRO, 2008).

\subsection{DISSIPADOR DE ENERGIA}

Como afirma Fendrich (1991), em muitos casos, quando a saída da água dos canais não ocorre em seções hidraulicamente estáveis, torna-se necessário um dissipador de energia, que resulte na redução da velocidade de saída em um regime adequado e, consequentemente, na estabilidade do corpo receptor no ponto de lançamento da própria obra.

Entretanto, a implantação das estruturas de dissipação de energia depende das características topográficas, hidráulicas e geológicas, além do desnível a ser transporto.

Alguns tipos de estruturas para dissipação de energia muito utilizados, como os degraus, estruturas que produzem o ressalto hidráulico, o qual é responsável por uma desaceleração do escoamento, sendo utilizados em locais onde se encontra uma declividade altamente elevada. São muito utilizados pela sua facilidade construtiva e viabilidade econômica.

Outro dissipador de energia é a Bradley-Petarka, onde a dissipação ocorre pelo impacto da água no defletor vertical suspenso e pela mudança de direção da corrente; sendo indicado para velocidades de $9 \mathrm{~m} / \mathrm{s}$ e descargas de até $11 \mathrm{~m}^{3}$, acrescentando 

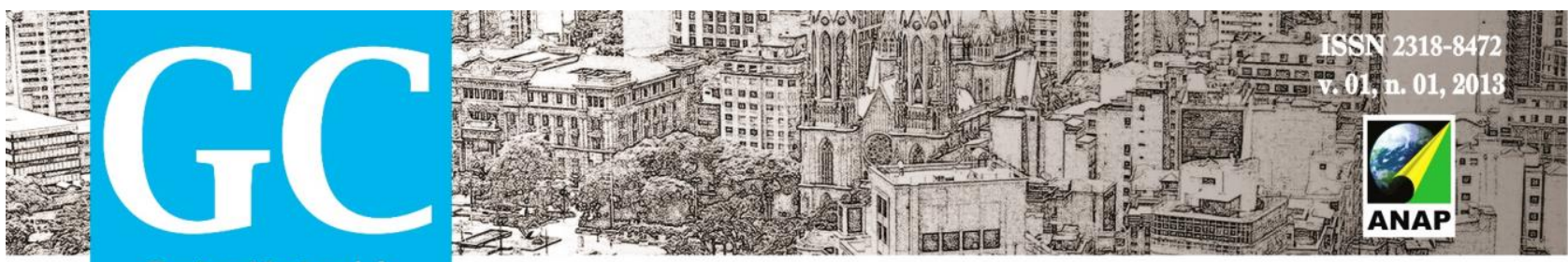

Revista Nacional de

Gerenciamento de Cidades

também um entroncamento complementar de proteção à jusante na estrutura (FENDRICK, 1991).

Importante destacar que o ponto de lançamento, onde se deve implantar um dissipador de energia, para um canal natural ou artificial é a parte final do sistema de microdrenagem, e inicial do de macrodrenagem, e recebe as águas pluviais da rede urbana. A preocupação principal para esse ponto é a possível erosão que possa ocorrer no solo, ocasionando perca de solo, assoreamento do corpo d'água e a própria destruição da estrutura da macrodrenagem.

\section{CONJUNTO HABITACIONAL EMÍLIO ZANATTA EM DRACENA-SP}

O sistema de drenagem faz parte do conjunto de melhoramentos públicos existentes em uma área urbana, e é conveniente, para a comunidade, que essa área seja planejada de forma integrada, isto é, que todos os melhoramentos públicos sejam planejados coerentemente. Porém, a prática mostra que isso não é o que acontece constantemente, como demonstram os levantamentos no conjunto habitacional Emílio Zanata, localizado na cidade de Dracena, interior paulista.

Esse empreendimento está inserido em uma bacia hidrográfica de aproximadamente $1.244 \mathrm{~m}^{2}$, onde, desse total $37,2 \%$ é área urbana e $62,8 \%$ rural, com o predomínio de pastagem. O sistema de drenagem no conjunto habitacional possui atualmente dois pontos de lançamento, um se encontra nas proximidades da área de lazer existente, próximo à estação elevatória de esgoto, e o outro na região sul do empreendimento, a aproximadamente $500 \mathrm{~m}$ do anterior.

Por meio de estudos de hidrologia e hidráulica realizados por escritório especializado (KMA Arquitetura e Urbanismo Ltda.) sobre o escoamento superficial existente no conjunto habitacional, identificou-se que não há problemas de captação do escoamento por meio do sistema de bocas de lobo existente para um período de retorno 


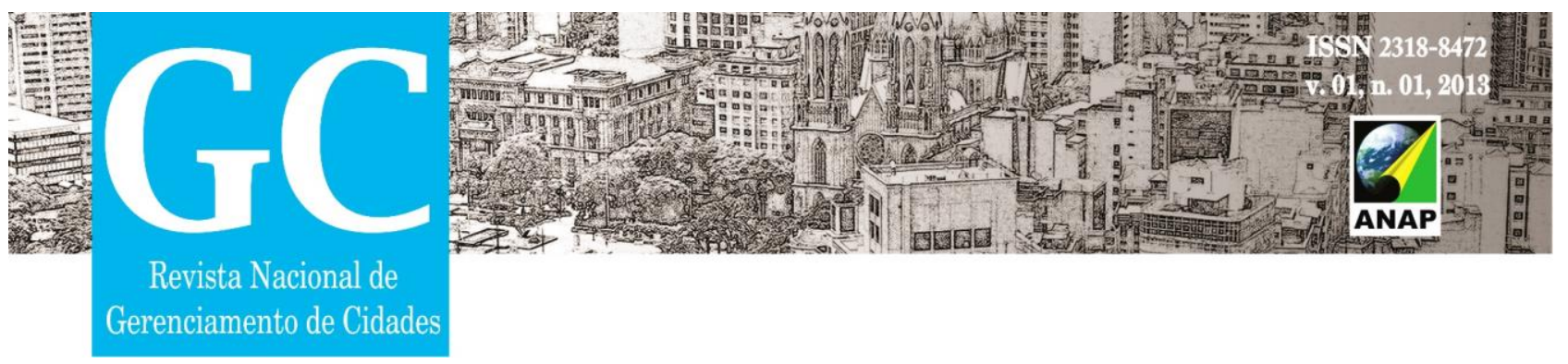

de 25 e 50 anos, mas sim um sério problema nos pontos de lançamento do sistema de drenagem.

Como dito, há dois pontos de lançamento nesse sistema local, ou seja, duas saídas de galerias com $2.000 \mathrm{~mm}$ de diâmetro cada, com processo de erosão avançado, ocasionando perda de solo e assoreando recursos hídricos pertencentes à bacia hidrográfica estudada. Percebe-se que as voçorocas existentes colocam em risco estradas e uma estação elevatória de esgoto. O problema se encontra na inexistência de estruturas hidráulicas que contenham uma vazão conhecida e diminua a velocidade de chegada da água, proporcionando um escoamento subcrítico.

O principal problema relacionado ao dimensionamento equivocado na saída da galeria é a falta de conhecimento da vazão que ali escoa; e sem os dados reais é impossível dimensionar um dissipador que amorteça a velocidade da água corretamente. Assim, os dissipadores (em degraus) são insuficiente para as vazões de pico.

A partir disso, outro problema ocorre, pois com as saídas superdimensionadas o dissipador não diminui a velocidade da água, causando grandes danos a jusante. Os principais prejuízos causados pela velocidade excessiva da água no local são: uma voçoroca com aproximadamente 600 metros de extensão com perda de solo, gerando prejuízo para os proprietários, assoreamento de recurso hídrico, destruição de estradas no perímetro, ameaça a estrutura da estação elevatória de esgoto do local, e risco à própria estrutura de macrodrenagem.

Sabendo-se dos principais problemas e suas causas, foi proposto que no final do sistema de captação fosse instalado um outro dissipador de energia, estrutura esta que segundo Fendrich (1991), possibilitaria reduzir a alta velocidade de saída a um regime tranquilo, garantindo a estabilidade do corpo receptor no ponto de lançamento, bem como a estabilidade da própria obra.

Também projetou-se a instalação de um reservatório de amortecimento, o qual atrasaria a cheia do sistema, contendo temporariamente um determinado volume de águas pluviais, ajudando assim na prevenção a processos erosivos no local, como o que tem ocorrido. 


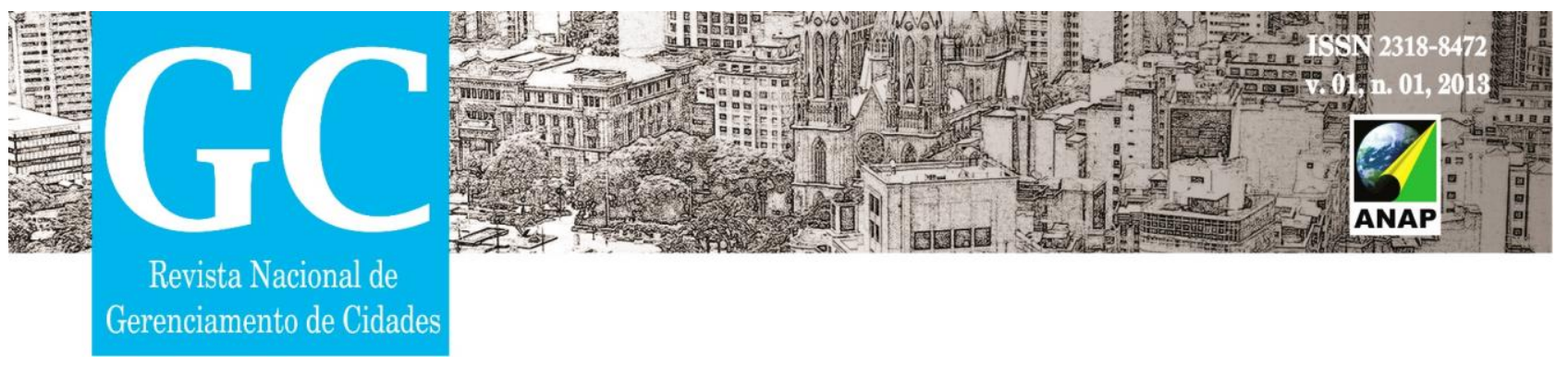

\section{CONSIDERAÇÕES FINAIS}

O presente trabalho visou a apresentar levantamentos elaborados na cidade de Dracena-SP, no conjunto habitacional Emílio Zanatta, e aspectos da drenagem urbana, por meio de suas estruturas físicas, caracterizando parte de seus elementos.

Verificou-se que o projeto e execução bem elaborados do sistema de drenagem pluvial - micro e macrodrenagem - são fundamentais para uma estrutura urbana que possibilite redução de prejuízos sociais, econômicos e ambientais, e melhora da saúde pública e qualidade de vida de seus habitantes.

Foi possível identificar aspectos relevantes do caso analisado, por meio dos levantamentos realizados, focando tanto nos elementos executados anteriormente como nos elementos que foram propostos para mitigação dos problemas existentes, como solução para problemas já causados.

Assim sendo, pode-se afirmar que a ausência de projetos bem elaborados de drenagem urbana auxilia na degradação do meio ambiente natural e construído, reduzindo a qualidade de vida de sua população, inclusive criando situações de risco devido a processos erosivos e de deslizamentos, além da ruptura possível do sistema e alagamentos de áreas urbanizadas.

Com isso, pretendeu-se contribuir com a reflexão sobre um assunto que deve fazer parte das agendas da administração pública, bem como de profissionais da área de planejamento ambiental, para que os estudos do tema de drenagem urbana não se esgotem, possibilitando a evolução não apenas tecnológica, mas também de gestão, legislação e educação.

\section{REFERÊNCIAS}

BRASIL. Estatuto da Cidade: guia para implementação pelos municípios e cidadãos: Lei no 10.257/2001. 2a .ed. Brasília: Câmara dos Deputados, Coordenação de Publicações, 2002.

BRASIL. Lei Federal $\mathbf{n}^{\circ} \mathbf{. 1 1 . 4 4 5}$, de 05 de janeiro de 2007. 


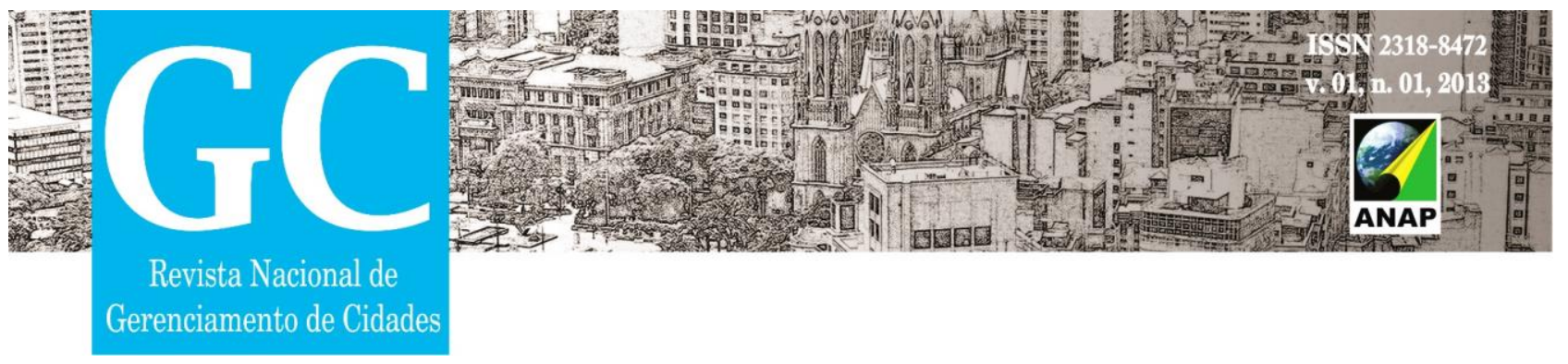

BRASIL. Ministério das Cidades. Secretaria Nacional de Saneamento Ambiental. Programa de Modernização do Setor Saneamento (PMSS). Instrumentos das políticas e da gestão dos serviços públicos de saneamento básico. Brasília, 2009.

BUARQUE, S. Metodologia de planejamento do desenvolvimento local e municipal sustentável. Brasilia: Instituto Interamericano de Cooperação para Agricultura, 1999. Disponível em: www.apodesc.org. Acesso em 30 de junho de 2011.

CANHOLI, A.P. Drenagem urbana e controle de enchentes. São Paulo: Oficina de Textos, 2005.

CAVALHEIRO, M.G. O processo de cheia em bacias hidrográficas urbanas. Presidente Priudente: UNOESTE, 2008 (Monografia de Graduação).

CHAMPS, J.R. Manejo de águas pluviais urbanas: o desafio da integração e da sustentabilidade. In: Conceitos, características e interfaces dos serviços públicos de saneamento básico, 2009.

DAEE/CETESB - DEPARTAMENTO DE ÁGUAS E ENERGIA ELÉTRICA / COMPANHIA DE TECNOLOGIA E SANEAMENTO AMBIENTAL. Drenagem urbana: manual de projeto. São Paulo: DAEE/CETESB, 1980.

DIAS, F.S.; ANTUNES, T. S. C. Estudo Comparativo de Projeto de Drenagem Convencional e Sustentável para Controle de Escoamento Superficial em Ambientes Urbanos. Rio de Janeiro: UFRJ, 2010. (Monografia de Graduação).

FENDRICH, R. et al. Drenagem e controle da erosão urbana. $3^{a}$.ed. São Paulo: IBRASA. Curitiba: Champagnat, 1997.

PORTO, R., et al. Drenagem Urbana. In: TUCCI, Carlos E. M., [et al.]. Hidrologia: Ciência e Aplicação. 4를. ed., Porto Alegre: Editora da UFRGS/ABRH, 2007.

RAIMUNDO, A.P. Estruturas Hidráulicas Utilizadas em Reservatórios de Controles de Cheias. São Paulo: USP, 2007 (Dissertação de Mestrado).

TUCCI, C.E.M. Hidrologia: ciência e aplicação. 2a $2^{\mathrm{a}}$.ed. Porto Alegre: Editora da Universidade - ABRH, 2000.

TUCCI, C.E.M. Elementos para o controle da drenagem urbana. In: Revista Brasileira de Recursos Hídricos. V2, N.1, p101-122, 1997. Rio Grande do Sul: Instituto de Pesquisas Hidráulicas - Universidade Federal do Rio Grande do Sul.

VIEIRA, M.C; SÁ, V.H.S. Aspectos da drenagem urbana: exemplificação de caso Bairro Emílio Zanatta. Presidente Priudente: UNOESTE, 2011 (Monografia de Graduação). 